\title{
Variation of the chemical components of macadamia in Vietnam at different harvesting maturity
}

\author{
${ }^{1, *}$ Loi, N.V. and ${ }^{2}$ Binh, P.T. \\ ${ }^{I}$ Faculty of Environmental Sciences, University of Science, Vietnam National University, Hanoi, 334 Nguyen \\ Trai Road, Thanh Xuan District, Nanoi, Vietnam \\ ${ }^{2}$ Faculty of Food Technology, Bac Giang Agriculture and Forestry University, Vietnam
}

\author{
Article history: \\ Received: 5 February 2021 \\ Received in revised form: 26 \\ March 2021 \\ Accepted: 10 June 2021 \\ Available Online: 20 \\ February 2022
}

\section{Keywords:}

Amino acid,

Chemical composition,

Harvest period,

Physicochemical criteria,

Macadamia

DOI:

https://doi.org/10.26656/fr.2017.6(1).090

\begin{abstract}
Currently, macadamia is harvested mainly by collecting ripe fruits. This way of harvesting is expensive due to the reduced quality of the fruits falling to the ground. Thus, it is necessary to analyze the chemical components of macadamia at different maturity to identify the best time for mass harvest. In our study, lipid, protein, and carbohydrate contents in the kernel of macadamia in the 3 stages of growing (including 175, 195, and 215 days after fruiting) were determined by using analytical methods. These components increased gradually and reached the maximum values of $78.2 \pm 0.1 \%, 9.3 \pm 0.1 \%$, and $7.8 \pm 0.2 \%$ for lipid, protein, and carbohydrate, respectively, 215 days after fruiting. Moreover, by using the HPLC method 13 amino acids, 14 amino acids, and 15 amino acids were identified at 175, 195, and 215 days after fruiting respectively. In all of these 3 stages, there were 7 non-substituting amino acids, including leucine, isoleucine, lysine, methionine, valine, phenylalanine, and histidine in the kernel of macadamia. The contents of phenylalanine, alanine, leucine, and glycine tended to increase in the developmental stages of macadamia. After 175 days, 195, and 215 days of harvest, 9 to 10 types of fatty acids were identified. Comparing two harvest times 195 and 215 days since fruiting, the fatty acid content of macadamia did not differ much. Therefore, the most appropriate time to harvest macadamia is from 195 to 215 days after fruiting.
\end{abstract}

\section{Introduction}

Macadamia has been planted in Vietnam since 1994. Vietnam has been promoting more planting of macadamia in areas such as the Central Highlands and the Northwest, thus, the country's macadamia growing areas are being expanded. This fruit contains many nutrients. However, it is mainly composed of lipids, proteins, and carbohydrates. The content of these ingredient changes with the time of harvest. In Vietnam, macadamia berries ripen within 6-7 months. Ripening time depends on the variety, different varieties have different ripening times. The seeds are ripe when the inside of the shell is black, meaning that it can be harvested at that time. When dried macadamia nut, the outer shell of the fruit is longitudinally cracked into 2 parts, exposing the hard seed shell, the seed germination hole is clearly visible, the outside has a small protrusion. Causality is milky white, the upper part is slightly smooth, the bottom is rough with ripples protruding vertically. This is the stage when the fruit is ripe. Usually, people rely on these characteristics to harvest and at this stage, the fruit often falls to the ground. The harvesting and processing of macadamia involve collecting ripe fruits on the ground, which leads to high costs. In addition, fruits falling to the ground are often susceptible to dust and reduced quality (Hoang, 2015). Therefore, the analysis and determination of the chemical composition of macadamia to select the time of mass harvest are necessary to overcome the previous problems.

Research results have shown that the lipid, protein, and carbohydrate content increased and reached the maximum value of $78.2 \pm 0.1 \%, 9.3 \pm 0.1 \%$, and $7.8 \pm 0.2 \%$ on day 215 , respectively. Using the HPLC method, the number of amino acids was determined after 175, 195, and 215 days of fruit set, respectively 13 amino acids, 14 amino acids, and 15 amino acids. Among those amino acids, phenylalanine, alanine, leucine, and glycine tended to increase while other acids remained unchanged. After 175 days, 195, and 215 days of harvest, 9 to 10 fatty acids were identified. Comparing the two harvesting times 195 and 215 days after the fruit set, the fatty acid 
content of macadamia nuts did not differ much. Therefore, the most suitable time to harvest macadamia in Vietnam is the period from 195 to 215 days after fruiting.

\section{Materials and methods}

\subsection{Materials}

Fresh macadamia grown from the seeds and named 695 (Beaumont) were collected at the planting time of 175 days, 195 days, and 215 days after fruiting in the 3 macadamia farms in Lai Chau province (the Northwest of Vietnam). Samples were randomly taken at the 3 stages with a total of 720 fruits, equally divided among 60 trees, and in different positions of the trees. After that, these samples were transferred to the laboratory, and the shells were peeled for analysis. The chemicals used in the study were diethyl ether, toluene, distilled water, calcium pectate, indigocarmine, and potassium manganate from Sigma.

\subsection{Determining the physical and chemical criteria of macadamia}

The diameters were determined by the numerical ruler (the error of $0.1 \mathrm{~mm}$ ). The weights were determined by using CP224S Sartorius analytical balance (accuracy to $0.0001 \mathrm{~g}$ ). Percentages of shells, seed coats, and kernels were determined by calculating their weights compared to the total weight of the fruit: After washing, draining, and peeling the shells, seed coats and kernels were weighed, and the percentages of shells, seed coats, and kernels were calculated.

\subsection{Determining the chemical composition in the kernel and the shells}

Determination of moisture content in the kernel and inside the shells was done by the distillation method with toluene (Nguyen and Nguyen, 2012): $10 \mathrm{~g}$ of crushed kernel or shells and $100 \mathrm{~mL}$ of anhydrous toluene were added to a $500 \mathrm{~mL}$ flask. Water element determination tools together with a reflux condenser were used. The mixture was boiled in the flask to a boiling temperature until no water was visible at the hydrograph. The volume of water collected at the measuring device was recorded. Water content in raw materials was determined by the following formula:

$$
W=\frac{V \cdot d \cdot 100}{m}(\%)
$$

Where W: Humidity of kernel or shells of macadamia (\%), m: Weight of kernel or shells of macadamia (g), V: Volume of water collected at measuring instrument $(\mathrm{mL})$, and d: Density of water $(\mathrm{g} /$ $\mathrm{mL})$.
Protein contents in the kernel and shells of macadamia were determined according to Vietnamese standards (TCVN 8133-1, 2009).

The content of internal carbohydrates and shells of macadamia were determined according to Vietnamese standards (TCVN 4594, 1998).

The lipid contents in the kernel and inside of the shells were determined according to the Soxhlet method (Tran and Cao, 2014).

The contents of minerals were determined as follows: $\mathrm{K}, \mathrm{Fe}$ was determined by the atomic absorption method on AAS-3300 (Perkin Elmer). Ca, Mg were determined by EDTA and $\mathrm{S}$ titration method, $\mathrm{P}$ was determined by complex color method at $885 \mathrm{~nm}$ wavelength on UV-Visible Spectrophotometer Cintra 40. Finally, $\mathrm{Zn}, \mathrm{Mn}, \mathrm{Cu}$ were determined according to Vietnam standard TCVN 1537: 2007 (Tran and Cao, 2014). The contents of vitamin $B_{1}$ and $B_{2}$ in the kernel and shells of macadamia were determined by the method of polarizing pulse spectrum (Nguyen et al., 2007). The contents of tannin in shells were determined according to the Leventhal method (Ha, 2009).

The contents of pectin in shells of macadamia were determined by the calcium pectate method. Based on the precipitate of calcium pectate salts, the amount of pectin taken for saponification was determined by the formula $\mathrm{B}=\mathrm{m} . \mathrm{V}_{2} / \mathrm{V}_{1}(\mathrm{~g})$, in which $\mathrm{m}$ : the weight of the calcium pectate precipitate $(\mathrm{g}), \mathrm{V}_{1}$ : volume of the initial pectin solution $(\mathrm{mL}), \mathrm{V}_{2}$ : volume of the pectin solution taken for saponification $(\mathrm{mL})$. Pectin contents were calculated by the formula $\mathrm{P}(\%)=\mathrm{m} .0 .92 * 100 / \mathrm{B}$, in which $\mathrm{m}$ : the weight of precipitated calcium pectate $(\mathrm{g}), \mathrm{B}$ : the amount of pectin taken and saponification (g), 0.92: conversion factor (Ha, 2009).

Amino acid contents in the kernel of macadamia were determined by the HPLC method by using Detector PAD 2996, fluorescence 2475, and Water model automatic pump of Water company (USA). The chromatographic column was Symmetry RP18 amino acid $(150 \mathrm{~mm} \times 4.6 \mathrm{~mm} \times 3.5 \mathrm{pm})$ and Symmetry Shield RP18 column $(150 \mathrm{~mm} \times 4.6 \mathrm{~mm} \times 5 \mathrm{pm})$ by Water. The mobile phase was a buffer solution of borates, acetonitrile, MiliQ water; The flow rate was $1 \mathrm{~mL} / \mathrm{min}$ and the column temperature was $35^{\circ} \mathrm{C}$. Amino acids were quantified by a fluorescence detector with excitation and emission wavelengths of $340 \mathrm{~nm}$ and 450 $\mathrm{nm}$, respectively (Le and Nguyen, 2007).

Fatty acids in macadamia oil were determined by gas chromatograph GC6890-MS5898, capillary column HT5MS: The injection sample volume is $1 \mathrm{~mL}$. Column temperature from $80-180^{\circ} \mathrm{C}$, the temperature of 
temperature increase every $3^{\circ} \mathrm{C} / \mathrm{min}$, keep at this temperature threshold for 5 mins; the column temperature ranges from 180 to $220^{\circ} \mathrm{C}$, the rate of temperature increase every $8^{\circ} \mathrm{C} / \mathrm{min}$, keep at this threshold for 5 mins. MS conditions: ionize the sample at an ionization potential of $70 \mathrm{EV}$, maintain the temperature at $250^{\circ} \mathrm{C}$, a carrier gas is helium, have a transport rate of $1.0 \mathrm{~mL} / \mathrm{min}$, and a flow rate of $1: 50$ (Pham et al., 1998).

\section{Results and discussion}

3.1 The change in size and the ratio of different fruit parts of macadamia harvested at different maturity

Fruit shells from fruits harvested at different maturity had varying sizes and fruit different fruit parts ratios (Table 1). On the 175 th day after fruiting, the shells of the fruits were dark green, thick; the shells of the kernels were yellow-ivory; the kernel rate was $42.3 \pm 0.3 \%$. By day 195 , the skin of the fruit was thin with an inner layer of yellow-brown color; the seed shell was hard; the fruit diameters were about $28 \pm 0.1$ $\mathrm{mm}$, and the kernel rates were about $47.1 \pm 0.3 \%$. After 215 days period, the peels were hard, dry, and cracked; the seed skins were brown, firm; the kernels were milky white; the upper parts were slightly smooth; the rough bottom had a protruding ripple in the vertical direction. The kernel rates were about $52.4 \pm 0.3 \%$, the weights of the kernels were about $8.5 \pm 0.5 \mathrm{~g}$. Thus, in the period from 175 days to 215 days, the ratios of fruits and kernel shells gradually decreased; the kernel rates, kernel weights, and diameters of the seeds increased. Therefore, based on the size, the rates of fruit in different fruit parts of macadamia could be harvested at the period of 195-215 days after fruiting.

\subsection{Chemical composition in the kernel of the} macadamia harvested at different maturity

Determination of the chemical compositions of the harvested kernels of the macadamia at different maturity has great practical applications because based on the results the appropriate harvesting time would be suggested to keep high values of the seeds. The results of the chemical compositions in the kernels of the macadamia were presented in Table 2 .

The results in Table 2 showed that, after 175 days, the contents of lipid, protein, and carbohydrate in the macadamia were $73.8 \pm 0.3 \%, 8.3 \pm 0.2 \%$, and $5.9 \pm 0.1 \%$ respectively; on the 195th day, these values tended to increase $(76.7 \pm 0.2 \%, \quad 8.7 \pm 0.2 \%, \quad$ and $\quad 6.5 \pm 0.1 \%$ respectively); whereas on the 215 th day, the contents of these components continued to increase and reached the highest values, including $78.2 \pm 0.1 \%, 9.3 \pm 0.1 \%$, and $7.8 \pm 0.2 \%$ respectively. In addition, 215 days after fruiting, the amounts of vitamin $\mathrm{B}_{1}$ and $\mathrm{B}_{2}$ were also highest. However, the water contents were reduced between 175 and 215 days. This is explained by the fact that the fruits reached the stage of aging and ripening, making the shells dry and cracked. In particular, the amount of water was about $2.5 \pm 0.1 \%$ of the dry weight on the 215th day. These results of the study were consistent with those of Hays (2001).

\subsection{The chemical composition of the shells harvested at different maturity}

Macadamia pods can be used as organic fertilizer, as feed for livestock and poultry. Therefore, the analysis of the chemical compositions of the shells (Table 3) could be valuable for the use of macadamia in the field of agriculture.

The results of the study in Table 3 show that there were many nutritional components in macadamia. After 175 days, young green shells of the macadamia contained a lot of water, and tannin content accounted for $16.5 \pm 0.2 \%$. Furthermore, at this stage, the macadamia was often harsh, and other chemical components were lower than those in 195-215 days.

Table 1. The size, the ratio of the structure of macadamia harvested at different maturity

\begin{tabular}{|c|c|c|c|c|}
\hline \multirow{2}{*}{ No. } & \multirow{2}{*}{ Analytical Parameter } & \multicolumn{3}{|c|}{ Days after fruiting } \\
\hline & & 175 days & 195 days & 215 days \\
\hline 1 & Fruit shape & Peach shape & Peach shape & Peach shape \\
\hline 2 & Fruit diameter (mm) & $20 \pm 0.1^{\mathrm{c}}$ & $28 \pm 0.1^{\mathrm{b}}$ & $30 \pm 0.1^{\mathrm{a}}$ \\
\hline 3 & Kernel diameter (mm) & $18 \pm 0.2^{\mathrm{b}}$ & $27 \pm 0.3^{\mathrm{a}}$ & $27 \pm 0.3^{\mathrm{a}}$ \\
\hline 4 & Kernel weight $(\mathrm{g})$ & $7.5 \pm 0.5^{\mathrm{c}}$ & $8.1 \pm 0.5^{\mathrm{b}}$ & $8.5 \pm 0.5^{\mathrm{a}}$ \\
\hline 5 & The ratio of shells (\%) & $29.2 \pm 0.3^{\mathrm{a}}$ & $27.2 \pm 0.3^{\mathrm{bc}}$ & $26.1 \pm 0.3^{\mathrm{c}}$ \\
\hline 6 & $\begin{array}{l}\text { The ratio of the seed coat } \\
(\%)\end{array}$ & $22.1 \pm 0.2^{\mathrm{a}}$ & $21.3 \pm 0.2^{\mathrm{ab}}$ & $20.2 \pm 0.2^{\mathrm{bc}}$ \\
\hline 7 & The ratio of the kernel (\%) & $42.3 \pm 0.3^{c}$ & $47.1 \pm 0.3^{b}$ & $52.4 \pm 0.3^{\mathrm{a}}$ \\
\hline
\end{tabular}

Values are presented as the mean \pm standard deviation. Values with the same superscript within the row are not significantly different $(\mathrm{P}<0.05)$. 
Table 2. The chemical composition of the kernel of the macadamia harvested at different maturity

\begin{tabular}{llccc}
\hline \multirow{2}{*}{ No. Chemical components } & \multicolumn{3}{c}{ Content of chemical components of the kernel by harvest date } \\
\cline { 2 - 5 } & 175 days & 195 days & 215 days \\
\hline 1 & Water (\%) & $6.3 \pm 0.2^{\mathrm{a}}$ & $3.7 \pm 0.1^{\mathrm{b}}$ & $2.5 \pm 0.1^{\mathrm{c}}$ \\
2 & Total lipids (\%) & $73.8 \pm 0.3^{\mathrm{c}}$ & $76.7 \pm 0.2^{\mathrm{b}}$ & $78.2 \pm 0.1^{\mathrm{a}}$ \\
3 & Total carbohydrate (\%) & $5.9 \pm 0.1^{\mathrm{c}}$ & $6.5 \pm 0.1^{\mathrm{b}}$ & $7.8 \pm 0.2^{\mathrm{a}}$ \\
4 & Total protein (\%) & $8.3 \pm 0.2^{\mathrm{c}}$ & $8.7 \pm 0.2^{\mathrm{b}}$ & $9.3 \pm 0.1^{\mathrm{a}}$ \\
5 & $\mathrm{~K}(\mathrm{mg} \%)$ & $0.29 \pm 0.1^{\mathrm{c}}$ & $0.32 \pm 0.1^{\mathrm{b}}$ & $0.37 \pm 0.1^{\mathrm{a}}$ \\
6 & $\mathrm{P}(\mathrm{mg} \%)$ & $0.12 \pm 0.01^{\mathrm{b}}$ & $0.15 \pm 0.01^{\mathrm{a}}$ & $0.16 \pm 0.01^{\mathrm{a}}$ \\
$7 \mathrm{Mg}(\mathrm{mg} \%)$ & $0.71 \pm 0.01^{\mathrm{c}}$ & $0.82 \pm 0.02^{\mathrm{b}}$ & $0.93 \pm 0.02^{\mathrm{a}}$ \\
$8 \mathrm{Ca}(\mathrm{mg} \%)$ & $0.028 \pm 0.002^{\mathrm{b}}$ & $0.029 \pm 0.001^{\mathrm{b}}$ & $0.036 \pm 0.001^{\mathrm{a}}$ \\
9 & $\mathrm{~S}(\mathrm{mg} \%)$ & $0.065 \pm 0.002^{\mathrm{b}}$ & $0.065 \pm 0.001^{\mathrm{b}}$ & $0.067 \pm 0.002^{\mathrm{a}}$ \\
$10 \mathrm{Fe}(\mathrm{mg} \%)$ & $0.017 \pm 0.001^{\mathrm{ab}}$ & $0.018 \pm 0.001^{\mathrm{a}}$ & $0.018 \pm 0.001^{\mathrm{a}}$ \\
$11 \mathrm{Zn}(\mathrm{mg} \%)$ & $0.012 \pm 0.001^{\mathrm{b}}$ & $0.014 \pm 0.002^{\mathrm{a}}$ & $0.014 \pm 0.001^{\mathrm{a}}$ \\
$12 \mathrm{Mn}(\mathrm{mg} \%)$ & $0.034 \pm 0.003$ & $0.035 \pm 0.001$ & $0.038 \pm 0.002^{\mathrm{a}}$ \\
$13 \mathrm{Cu}(\mathrm{mg} \%)$ & $0.031 \pm 0.002^{\mathrm{b}}$ & $0.031 \pm 0.002^{\mathrm{b}}$ & $0.033 \pm 0.001^{\mathrm{a}}$ \\
$14 \mathrm{Vitamin} \mathrm{B}_{1}(\mathrm{mg} \%)$ & $0.018 \pm 0.001^{\mathrm{bc}}$ & $0.019 \pm 0.001^{\mathrm{b}}$ & $0.021 \pm 0.001^{\mathrm{a}}$ \\
$15 \mathrm{Vitamin} \mathrm{B}_{2}(\mathrm{mg} \%)$ & $0.011 \pm 0.001^{\mathrm{ab}}$ & $0.011 \pm 0.001^{\mathrm{ab}}$ & $0.012 \pm 0.001^{\mathrm{a}}$ \\
\hline
\end{tabular}

Values are presented as the mean \pm standard deviation. Values with the same superscript within the row are not significantly different $(\mathrm{P}<0.05)$.

Table 3. The chemical composition of the macadamia harvested at different maturity

\begin{tabular}{|c|c|c|c|c|}
\hline \multirow{2}{*}{ No. } & \multirow{2}{*}{ Chemical components } & \multicolumn{3}{|c|}{ Content of chemical components by harvest date } \\
\hline & & 175 days & 195 days & 215 days \\
\hline 1 & Water $(\%)$ & $57.2 \pm 0.3^{\mathrm{a}}$ & $53.1 \pm 0.2^{b}$ & $49.3 \pm 0.1^{\mathrm{c}}$ \\
\hline 2 & Tannin $(\%)$ & $16.5 \pm 0.2^{\mathrm{a}}$ & $15.2 \pm 0.1^{\mathrm{b}}$ & $13.4 \pm 0.2^{\mathrm{c}}$ \\
\hline 3 & Total protein $(\%)$ & $6.1 \pm 0.2^{\mathrm{b}}$ & $8.2 \pm 0.2^{\mathrm{a}}$ & $8.2 \pm 0.1^{\mathrm{a}}$ \\
\hline 4 & Total carbohydrate $(\%)$ & $7.9 \pm 0.1^{\mathrm{c}}$ & $8.3 \pm 0.2^{b}$ & $8.9 \pm 0.1^{\mathrm{a}}$ \\
\hline 5 & Total lipid (\%) & $5.2 \pm 0.1^{\mathrm{c}}$ & $5.7 \pm 0.1^{\mathrm{b}}$ & $6.9 \pm 0.2^{\mathrm{a}}$ \\
\hline 6 & Pectin $(\%)$ & $3.2 \pm 0.2^{\mathrm{c}}$ & $3.9 \pm 0.1^{\mathrm{b}}$ & $4.1 \pm 0.1^{\mathrm{a}}$ \\
\hline 7 & $\mathrm{~K}(\mathrm{mg} \%)$ & $0.02 \pm 0.003^{\mathrm{b}}$ & $0.02 \pm 0.003^{\mathrm{b}}$ & $0.04 \pm 0.001^{\mathrm{a}}$ \\
\hline 8 & $\mathrm{P}(\mathrm{mg} \%)$ & $0.03 \pm 0.001^{\mathrm{b}}$ & $0.03 \pm 0.002^{\mathrm{b}}$ & $0.05 \pm 0.002^{\mathrm{a}}$ \\
\hline 9 & $\operatorname{Mg}(\mathrm{mg} \%)$ & $0.02 \pm 0.002^{b}$ & $0.04 \pm 0.003^{\mathrm{a}}$ & $0.04 \pm 0.002^{\mathrm{a}}$ \\
\hline 10 & $\mathrm{Ca}(\mathrm{mg} \%)$ & $0.5 \pm 0.03^{\mathrm{ab}}$ & $0.6 \pm 0.002^{\mathrm{a}}$ & $0.6 \pm 0.001^{\mathrm{a}}$ \\
\hline 11 & $\mathrm{~S}(\mathrm{mg} \%)$ & $0.6 \pm 0.02^{\mathrm{ab}}$ & $0.7 \pm 0.02^{\mathrm{a}}$ & $0.7 \pm 0.01^{\mathrm{a}}$ \\
\hline 12 & $\mathrm{Fe}(\mathrm{mg} \%)$ & $0.01 \pm 0.001^{\mathrm{ab}}$ & $0.01 \pm 0.001^{\mathrm{ab}}$ & $0.015 \pm 0.002^{\mathrm{a}}$ \\
\hline 13 & $\mathrm{Zn}(\mathrm{mg} \%)$ & $0.01 \pm 0.002^{\mathrm{ab}}$ & $0.01 \pm 0.001^{\mathrm{ab}}$ & $0.012 \pm 0.001^{\mathrm{a}}$ \\
\hline 14 & $\mathrm{Mn}(\mathrm{mg} \%)$ & $0.01 \pm 0.001^{\mathrm{ab}}$ & $0.01 \pm 0.002^{\mathrm{ab}}$ & $0.02 \pm 0.002^{\mathrm{a}}$ \\
\hline 15 & $\mathrm{Cu}(\mathrm{mg} \%)$ & $0.02 \pm 0.003^{\mathrm{ab}}$ & $0.025 \pm 0.001^{\mathrm{a}}$ & $0.025 \pm 0.001^{\mathrm{a}}$ \\
\hline 16 & Vitamin $\mathrm{B}_{1}(\mathrm{mg} \%)$ & $0.02 \pm 0.002^{\mathrm{c}}$ & $0.022 \pm 0.002^{\mathrm{b}}$ & $0.028 \pm 0.001^{\mathrm{a}}$ \\
\hline 17 & Vitamin $\mathrm{B}_{2}(\mathrm{mg} \%)$ & $0.01 \pm 0.002^{\mathrm{bc}}$ & $0.013 \pm 0.001^{\mathrm{b}}$ & $0.017 \pm 0.002^{\mathrm{a}}$ \\
\hline
\end{tabular}

Values are presented as the mean \pm standard deviation. Values with the same superscript within the row are not significantly different $(\mathrm{P}<0.05)$.

During the period from 195 to 215 days, macadamia was ripped, and the amount of water was reduced over time. The total contents of carbohydrates, lipids, minerals, and vitamins in the macadamia also increased gradually with the development stages of the fruit. Within the 215 days, total lipid and carbohydrate contents were accounted for $6.9 \pm 0.2 \%$ and $8.9 \pm 0.1 \%$, respectively. However, the total protein remained unchanged during all 3 studied stages.

\subsection{The change of amino acid content in the kernel of macadamia harvested at different maturity}

In addition to the changes in size, and ratios of the structure of macadamia harvested at different maturity, there were also changes in the contents of amino acids in these periods (Table 4). At these stages (175 days, 195 days, and 215 days after fruiting) 13 amino acids, 14 amino acids, and 15 amino acids were identified, respectively. Among those, there were 7 non-substituting amino acids, including leucine, isoleucine, lysine, methionine, valine, phenylalanine, and histidine. Serine and cysteine only appeared 195 and 215 days after fruiting. Moreover, phenylalanine, alanine, leucine, and glycine tended to increase in the developmental stages of macadamia, whereas the other amino acids did not change much. 
Table 4. The change of amino acid content in the kernel of macadamia harvested at different maturity

\begin{tabular}{clccc}
\hline \multirow{2}{*}{ No. } & \multirow{2}{*}{ Amino acids } & \multicolumn{3}{c}{ Content of amino acids content by harvest date (\%) } \\
\cline { 2 - 5 } & 175 days & 195 days & 215 days \\
\hline 1 & Aspartic & 4.75 & 4.13 & 3.07 \\
2 & Serine & No detectable & 4.38 & 3.73 \\
3 & Glutamic & 4.54 & 4.17 & 3.67 \\
4 & Glycine & 9.19 & 9.04 & 13.72 \\
5 & Histidine & 5.67 & 5.43 & 3.04 \\
6 & Alanine & 9.15 & 9.06 & 12.78 \\
7 & Proline & 6.76 & 6.25 & 3.72 \\
8 & Tyrosine & 8.13 & 8.07 & 6.09 \\
9 & Cysteine & No detectable & No detectable & 1.87 \\
10 & Valine & 9.25 & 9.24 & 6.34 \\
11 & Methionine & 8.17 & 8.16 & 6.19 \\
12 & Lysine & 3.81 & 3.75 & 2.23 \\
13 & Isoleucine & 8.14 & 8.01 & 6.18 \\
14 & Leucine & 9.42 & 9.08 & 12.52 \\
15 & Phenylalanine & 10.43 & 10.15 & 14.04 \\
\hline & Total & 97.41 & 98.92 & 99.19 \\
\hline
\end{tabular}

Note: Ratios (\%) were calculated according to the chromatographic peak areas

3.5 The change of fatty acid content in the kernel of macadamia harvested at different maturity

During the growth and development of macadamia, the content of nutritional components in general and fatty acids, in particular, are always changing. Determination of fatty acid composition in macadamia is an important criterion for evaluating the quality of this fruit. The results of determining the content of fatty acids in macadamia at different harvesting stages are shown in Table 5, Figures 1, 2, and 3.

Table 5, Figures 1, 2, and 3 show that at the time of harvest 175 days, 9 fatty acids were identified in macadamia. Three unsaturated fatty acids contain one double-bonded $76.12 \%$, some fatty acids account for a high proportion, such as oleic acid (C18:1) accounting for $62.21 \%$, palmitoleic acid (C16: 1) accounts for the proportion of $11.13 \%$ rate. Also, there is an unsaturated fatty acid-containing two double bonds and five unsaturated fatty acids, which account for $21.74 \%$. At harvest 195 and 215 days from fruiting obtained 10 fatty acids, of which three unsaturated fatty acids contain one double bond, one fatty acid contains two double bonds, and six saturated fatty acids. Of the 10 fatty acids, oleic acid (C18: 1) and palmitoleic acid (C16: 1) are fatty acids that account for a high proportion of macadamia. Comparing the two harvest periods 195 and 215 days since fruiting, the results showed that at these two stages, there was not much difference in the fatty acid content of macadamia.

\section{Conclusion}

The study results show that, in the period from 175 days to 215 days after fruiting, the ratios of shells and kernels decreased, but the kernel rates, weights, and diameters of the kernels increased gradually. In the stage of 175 days after fruiting, lipid, protein, and carbohydrate contents were $73.8 \pm 0.3 \%, 8.3 \pm 0.2 \%$, and

Table 5 The fatty acid composition of the macadamia at different maturity

\begin{tabular}{llccc}
\hline \multirow{2}{*}{ No. } & \multicolumn{1}{c}{$\begin{array}{c}\text { Fatty acids } \\
(\%)\end{array}$} & \multicolumn{3}{c}{ Content of fatty acids content by harvest date (\%) } \\
\cline { 2 - 5 } & Myristic acid (C14: 0) & 0.39 & 195 days & 215 days \\
\hline 1 & 3.25 & 3.39 & 0.42 \\
2 & Pentadecanoic acid (C15: 0) & 7.91 & 7.94 & 3.13 \\
3 & Palmitic acid (C16: 0) & 11.13 & 11.14 & 8.01 \\
4 & Palmitoleic acid (C16: 1) & 3.74 & 3.69 & 11.14 \\
5 & Stearic acid (C18: 0) & 62.21 & 64.21 & 64.67 \\
6 & Oleic acid (C18: 1) & 2.89 & 2.89 & 2.91 \\
7 & Linoleic acid (C18: 2) & 3.56 & 3.57 & 3.52 \\
8 & Arachidonic acid (20: 0) & 2.78 & 2.81 & 2.79 \\
9 & Eicosenoic acid (C20: 1) & - & 0.03 & 0.03 \\
10 & Behenic acid (C22: 0) & 18.85 & 18.74 & 18.78 \\
& Total saturated fatty acids & 76.12 & 78.16 & 78.16 \\
& Total unsaturated monounsaturated fatty acids & 2.89 & 2.89 & 2.91 \\
\hline & Total polyunsaturated fatty acids & 97.42 & 97.86 & 99.79 \\
\hline \multicolumn{2}{r}{ Total } &
\end{tabular}

Note: Ratios (\%) were calculated according to the chromatographic peak areas 


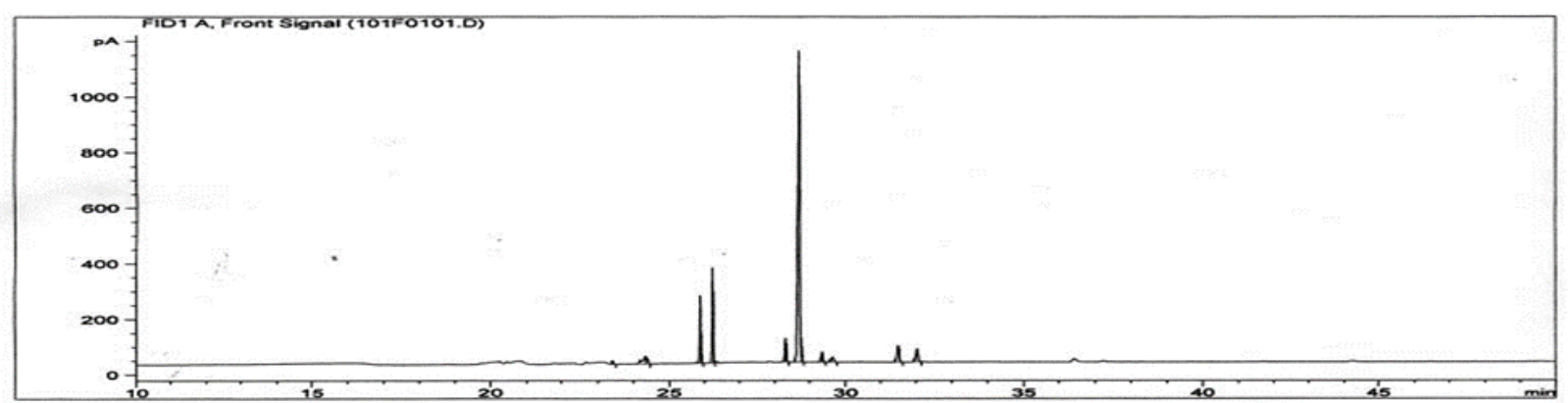

Figure 1. Chromatogram of the fatty acid composition of macadamia at 175 days from fruiting

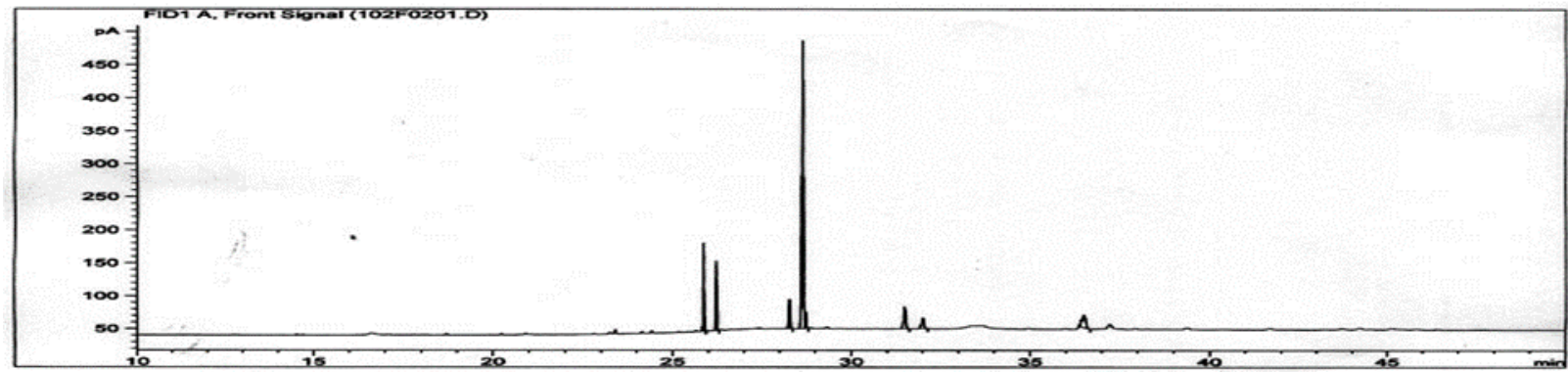

Figure 2. Chromatogram of the fatty acid composition of macadamia at 195 days from fruiting

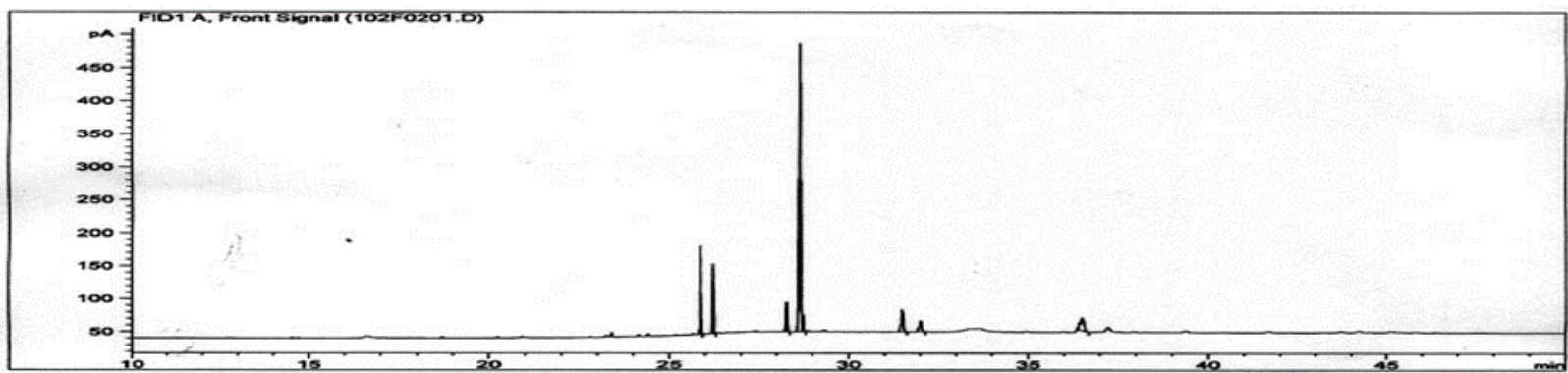

Figure 3. Chromatogram of the fatty acid composition of macadamia at 215 days from fruiting

$5.9 \pm 0.1 \%$, respectively; and the contents of these components increased and reached the maximal values of $78.2 \pm 0.1 \%, 9.3 \pm 0.1 \%$, and $7.8 \pm 0.2 \%$ respectively on the 215th day. By using the HPLC method, 13 amino acids, 14 amino acids, and 15 amino acids were identified 175, 195, and 215 days after fruiting, respectively. Among those amino acids, phenylalanine, alanine, leucine, and glycine tended to increase and the others did not change much. After 175 days, 195, and 215 days of harvest, 9 to 10 types of fatty acids were identified. Comparing two harvest times 195 and 215 days since fruiting, the fatty acid content of macadamia did not differ much. Therefore, the most appropriate time to harvest macadamia in Vietnam is suggested to be in the period from 195 to 215 days after fruiting.

\section{Conflict of interest}

The author declares the research results in this article to be completely honest. The data has never been used or rotated from other research projects in any form.

\section{Acknowledgments}

This work was completed thanks to the funding support from the State-level project: Research and application of biotechnology to produce several foods and animal feed. This research belongs to the project of biotechnology development and application in the processing industry by 2020 assigned by the Government to the Ministry of Industry and Trade for management.

\section{References}

Ha, D.T. (2009). Food chemistry analysis, p. 241-266. Vietnam: Publishing Scientific and Technical. EBook.

Hays, M. (2001). Macadamia kernels. American Journal of Botany, 95(7), 843-870.

Hoang, H. (2015). World macadamia industry and lessons for Vietnam, p. 7-10. Vietnam: Agricultural publisher.

Le, T.H.H. and Nguyen, T.D. (2007). Determination of some amino acids in soybean and processed products by high-performance liquid chromatography technique. Journal of Nutrition and Food - Vietnam Nutrition Association, 3(4), 68-77.

Nguyen, B.N., Nguyen, T.V.H. and Tu, V.N. (2007). Determination of vitamin $\mathrm{B}_{1}, \mathrm{~B}_{2}$, and $\mathrm{B}_{6}$ content by the method of polar spectrum pulse differential. Journal of Chemistry, Physics, and Biology, 12(3), 44-47

Nguyen, T.M.T. and Nguyen, V.L. (2012). Study on the use of saponin collected from teabag residues in 
citrus preservation. Journal of Science and Technology, 3A, 247-253.

Pham, T.K.T., Nguyen, X.D. and Le, T.H. (1998). Capillary gas chromatography is used to determine the composition of fatty acids in vegetable oils. Journal of Analytical Chemistry, Physics, and Biology, 3(2), 6-11.

Tran, T.T.H. and Cao, P.B. (2014). Determination of lipid, mineral, fatty acid and biochemical parameters in Sesamum indicum L. Journal of Science and Development, 12(7), 1029-1033.

Vietnamese National Standards. (2000). Determination of total protein content in oilseeds - Requirements with guidance for use (ISO 16634-1:2008). TCVN 8133-1: 2009. Retrieved from https://www.iso.org/ standard/46328.html.

Vietnamese National Standards. (1998). Canned foods Determination of total sugar and starch content Requirements with guidance for use (ST SEV 3450 81, IDT, 1998). TCVN 4594. Retrieved fromhttps:// tieuchuan.vsqi.gov.vn/tieuchuan/view?

sohieu=TCVN\%204594:1988 